One matter of some interest may be mentioned in conclusion. Cabannes and Dufay found in the light of the night sky a yellow line which they suspected to be sodium, and during the present year they have been able to show conclusively that sodium lines are present. Bernard showed that this sodium doublet is emitted by the very high layers of the atmosphere, the line being greatly intensified at twilight when the upper atmosphere is illuminated by the sun. What is the origin of this sodium ? Does it come from the earth where small crystals of sodium chloride exist in abundance, or is it interstellar sodium which the earth has picked up in its journey through space ? How are the sodium atoms excited? Perhaps solar radiation may be able to produce this excitation, but this, like the other points, cannot be answered at the moment, and we must await future research for light on the subject.

Non-astronomers will find much of the lecture readable and they will be amply repaid for the time spent on studying the numerous matters of interest dealt with by Prof. Fabry.

\title{
H. T. de la Beche: Geologist and Business Man
}

\author{
By Dr. F. J. North, National Museum of Wales
}

$F^{\mathrm{H}}$ EBRUARY 16, 1839, was an important date in the history of the Geological Survey, for on that day Mr. (as he was then) H. T. de la Beche wrote a letter which eventually resulted in the Survey being changed from a one-man affair, with no settled headquarters, to a great organization with an office in London*. It was something to have persuaded the Government to make a grant of $£ 300$ for the purpose of colouring geologically a few sheets of the Ordnance Survey map, but a geological survey of the whole of England and Wales was quite another matter, and, like Oliver Twist, de la Beche was continually asking for more-money for instruments, a travelling allowance, and permission to extend the survey into other parts of the country. He was not only able to envisage a National Geological Survey but he had also the courage and perseverance to overcome official inertia in order to establish it.

It is the object of this note to illustrate, by reference to one of his campaigns for the expansion of his work, the kind of man he was and the debt which geology owes to him. It is based upon de la Beche manuscripts deposited by the late Colonel J. I. D. Nicholl in the Geological Department of the National Museum of Wales, and upon some old letter books of the Ordnance Survey, to which, by kind permission of the Director, I was given access.

When the geological mapping which de la Beche had been allowed to undertake in Devon, Cornwall and Somerset was nearing completion, he obtained permission to continue the survey in South Wales, where he found a willing voluntary collaborator in W. E. Logan, then a young man engaged in the copper smelting business, and also received help in the field from one of the Ordnance surveyors, Henry McLauchlan. This help was, however, local and occasional, and arguing that, on the basis of his work in Devon, he could not hope to cover the whole of England and Wales in less than twenty-one years, de la Beche decided to seek permission to secure constant assistance with the view of completing the map in about ten years, and in a letter to Colonel Colby, the director of the Ordnance Survey (February 16, 1839), he wrote:

"It being an object of importance that the Geological Survey should be rendered as efficient as the

* A brief account of the early history of the Geological Survey was given by Sir John Flett in "The First Hundred Years of the Geological Survey of Great Britain" (1937), which was reviewed in NATURE of November 27, 1937. money granted for the service will permit, . . . I would respectfully suggest for the consideration of the Honourable Board of Ordnance that I should be permitted to hire such Geological Assistants as I may consider requisite for the proper execution of the work . . . such geological assistants to be chosen by myself and discharged by myself as may in my judgment appear reasonable and proper. . . . I would propose that I should not award any rates of pay exceeding ten shillings per day without special authority from the Honourable Board, and that I should send a quarterly return for the Honourable Board's information, showing the names and rates of pay of the persons so employed."

During the previous five years many letters concerning finance had passed between de la Beche and his employers, and his new application shows that he had profited by his experience. His opening remarks related to efficiency and economy, in his conclusion he disarmed criticism by offering to lay all his cards upon the table, whilst a condition that he knew from experience would be one of vital importance was inconspicuously inserted in the middle.

As usual, the Inspector General of Fortifications was cautious, and he endorsed the application as follows : "I know of no authority for the extensive view here taken of extending the Geological Research beyond the eight sheets of the Ordnance Survey authorized by the Master General's and Board's order of the 2nd May, 1832, and I should beg to submit the expediency of not proceeding . . . until something like an approximate estimate of the whole intended outlay be submitted to Parliament in the usual way."

The result of this endorsement was a letter to Colby stating that "The Master General and the Board are decidedly of opinion that it will never do to go on with this Geological Survey without some distinct rules by which the expense is to be governed. They are desirous of affording $\mathrm{Mr}$. de la Beche every facility, but it must be on some express understanding as to the extent of work to be executed, and the length of time to be occupied. By reference to the original arrangement it will be seen that a most material departure has already taken place from what was then proposed, and . . . what is now asked for will lead to an unlimited expenditure of time and money."

De la Beche was asked to indicate how long the whole work would take, and how much it would cost, 
and in reply he explained that it was not possible to estimate "the cost of Geological Surveys and the time necessary for their completion, as until some examination of a given area has been effected no correct idea of the whole expenditure can be formed". The region then under consideration was South Wales, and, he continued, "The coal and iron districts require great care both in scientific and economic points of view, and hence far more time has to be bestowed upon them, than upon most other portions of the country . . . but perhaps thrown in with South Wales generally the whole may be taken at about $£ 1$ per square mile".

Colby also replied to the Board, pointing out that the letter which he had received "contains no reply whatever to the original question of $\mathrm{Mr}$. De la Beche being permitted to hire assistants", and stating that he (Colby) had realized the necessity for hiring assistants during the progress of the work in Devonshire.

Careful handling of the situation eventually resulted in an official acknowledgment that it was not possible to foresee and to legislate for every contingency that was likely to arise during the course of a geological survey, and on March 15 it was reported that, "The Master General and Board consider the explanation given to be so far satisfactory as that it limits his labours to the completion of certain parts of the Survey for which the authority of the Treasury has been obtained, and to this he must be confined until the Master General and Board receive further instructions on the subject. With respect to the expenditure, the only plan . . . will be, from year to year, to take such a sum as may be deemed advisable, upon which point the Master General and Board would from time to time avail themselves of your opinion and so check any extraordinary expense that may be proposed".

De la Beche was quick to act upon the recommendation, for in April he wrote, in a letter to Colby : "I have picked up one very clever hand as an assistant at $7 \mathrm{~s}$. per day, a regular good one he is, and I am now on the look out for others". The "regular good one" was David Hiram Williams, who after rendering useful service in South Wales joined the Indian Survey, and his name was given in the "Return of Geological Assistants employed on the Geological Survey of England and Wales", which de la Beche made in June 1839. It will be noted that he wrote of the "Survey of England and Wales", although at the time he had only had authority to work in South Wales.

The "Return" for September 1839 contained two names, for Josiah Rees had been appointed at a salary of five shillings a day, and in December, when de la Beche submitted his estimates for the coming year, he budgeted for four assistants and a total expenditure of $£ 1,400$, while in the following year he budgeted for six, and a total expenditure of $£ 1,900$ -but the question of the possible limit to the duration of the Survey was not raised again, and before the work in South Wales was completed de la Beche was seeking permission to extend his operations into the Forest of Dean!

\section{Hydrogenation of Oils by the Continuous Process}

$\mathrm{V}$ T. Athavale and S. K. K. Jatkar have recently carried out a detailed study of hydrogenation of ethyl oleate using nickel-carbonate kieselguhr catalyst ( $J$. Indian Inst. Sci., 21, A, Part 25, 1938) and show a definite advance on previously recorded results. Iodine values, refractive indices and dispersions were determined on a number of samples of hydrogenated ethyl oleate, and results are recorded graphically. Contrary to expectation, iodine values did not vary linearly with refractive index in the initial stages of hydrogenation, but only after the iodine value had fallen by about twenty-five per cent. Comparison of refractive index and dispersion values of samples hydrogenated at different temperatures and with different rates of flow of ethyl oleate over the catalyst showed that dispersions of samples having almost identical refractive indices vary considerably. Similarly, it was found that samples having the same iodine value had dissimilar dispersions, thus indicating the formation of oleic acid during the reaction. A study of the effect of temperature on the velocity of hydrogenation at a fixed rate of flow of ethyl oleate over the catalyst further revealed a marked difference in dispersion values of samples hydrogenated at low temperatures and the conclusion was, therefore, reached that the isomers of oleic acid are formed because of the low activity for hydrogenation of the catalyst at low temperatures.

Interconnected with this research a further series of experiments were undertaken by the same authors (J. Indian Inst. Sci., 21, A, Part 26, 1938). Earlier work had pointed to the possibility that variations in velocity coefficients of hydrogenation of oils might be due not only to differences in composition of the oils, but equally to differences in the heterogeneity of the catalyst surface. Consequently, a study was undertaken of the velocity coefficients for the hydrogenation of ground-nut oil in the presence of nickelcarbonate-kieselguhr, unsupported nickel-carbonate, nickel-hydroxide-silica gel and nickel-peroxide-kieselguhr catalysts. A comparison was then made with the velocity coefficients of hydrogenation of the same oil over a nickel-wire catalyst. Velocity coefficients $(K)$ were calculated from the equation:

$$
K=\frac{2 \cdot 3}{t} \log \frac{a}{(a-x)} ;
$$

where $x$ is the percentage conversion at a given rate and $t$ is the time of contact. This velocity coefficient was further corrected for the effect of absorption

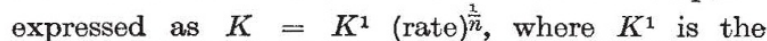
corrected velocity coefficient. By plotting the value $K^{1}$ for different samples of oil against temperature, curves showing a maximum at $150^{\circ}$ were obtained. This appeared to depend upon the percentage of olein in the oil and its selective hydrogenation at that temperature. 